\title{
ACCIDENTAL POISONING BY DIEFFENBACHIA (DUMB CANE) PLANT- A MUST KNOW FOR EMERGENCY PHYSICIAN
}

\author{
Rajesh Kulkarni, Aarti Kinikar, Tanvi Modi, Takam Kanu, K C Aathira, Arvinder Kaur, Priitee Ahir \\ Department of Pediatrics, B J Govt Medical College, Pune, Maharashtra, India.
}

The Dieffenbachia plant or "dumb cane" or "elephant's ear" is a plant native to Latin American countries and popularly used as an ornamental plant in homes. ${ }^{1}$ There have been cases of accidental ingestion of the stem, leaves or resin exuding from the cut stem due to its resemblance to sugarcane. ${ }^{2}$ Accidental ingestion of these may cause a severe erythematous reaction of the oral mucosa resembling angioedema or even anaphylaxis. ${ }^{3}$ A 6-year-old boy presented to the paediatric emergency with 2-3 episodes of vomiting, burning sensation in the mouth and throat, dysphagia, tongue swelling and drooling of saliva after he sucked on the stem of a plant, he believed to be sugarcane (Figure 1). On examination, there was swelling of the tongue, drooling of saliva, multiple ulcers on the buccal mucosa on the left side with mucosal edema and white blebs over the left lateral aspect of the tongue (Figure 2). He was given intravenous (IV) fluids, hydrocortisone, antihistamines, sodium bicarbonate rinses and kept nil by mouth for 24 hours. After 2 days, the mucosal erythema subsided; mucosal edema disappeared completely as did the blebs on his tongue.

Dieffenbachia is a very commonly used decorative plant which has proven to be very dangerous if ingested due to progressive swelling of tongue and adjacent tissues interfering with the airway, causing respiratory distress. Dieffenbachia causes severe local injury to the tissues due to the insoluble calcium oxalate crystals present in the plant juice. There are reports of airway compromise due to accidental ingestion. ${ }^{4}$ Due to the nature of the presentation, exposure can easily be

Figure 1. Dieffenbachia plant stem

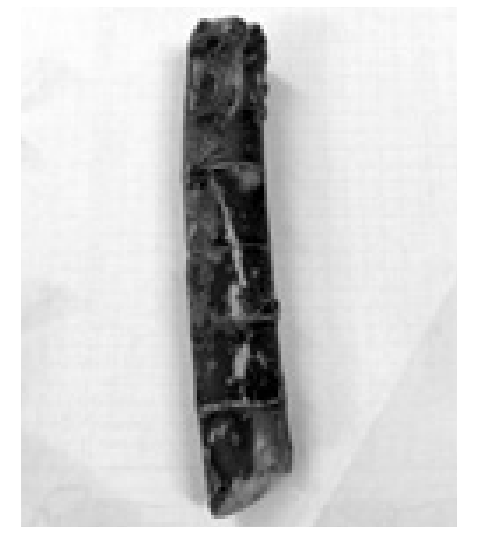

CONTACT Rajesh Kulkarni

Email: docrajesh75@yahoo.com

Address for Correspondence: Dr Rajesh Kulkarni, Department of Pediatrics, B J Govt Medical College, Pune, Maharashtra, India.

(c)2020 Pediatric Oncall

\author{
ARTICLE HISTORY \\ Received 03 Sep 2019 \\ Accepted 03 Sep 2019 \\ KEYWORDS \\ elephant's ear, Sugar cane, \\ ingestion, anaphylaxis
}

Figure 2. Swelling and bleb formation on tongue following accidental ingestion of Dieffenbachia stem

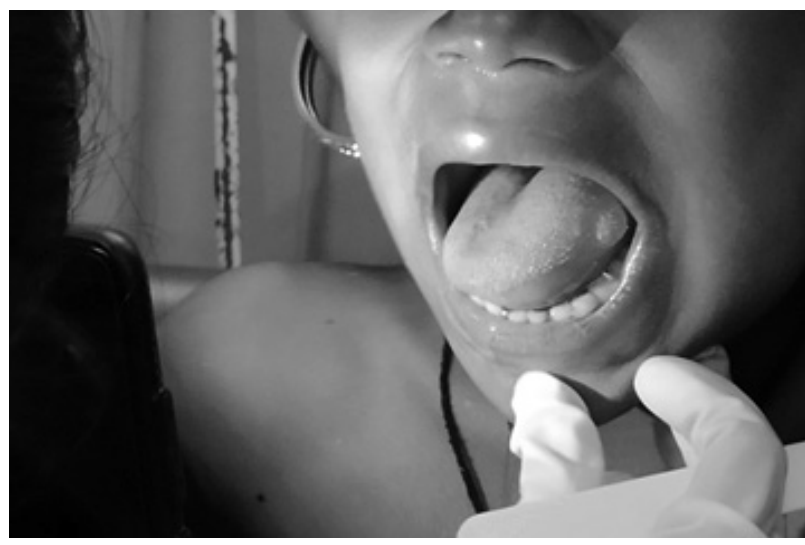

misdiagnosed as anaphylaxis or angioedema. Even the patient who initially seems stable may have an airway that will quickly deteriorate. Close observation of the child to prevent airway compromise along with analgesics, sodium bicarbonate gargles and IV fluids along with corticosteroids and antihistamines may be required. Educating the people about the identification of this plant and the toxic effects of its consumption is crucial to prevent more such instances in the future.

\section{Compliance with Ethical Standards \\ Funding: None \\ Conflict of Interest: None}

\section{References :}

1. Tagwireyi D, Ball DE. The management of Elephant's Ear poisoning. Hum Exp Toxicol. 2001;20(4):189-92.

2. Mrvos R, Dean BS, Krenzelok EP. Philodendron/ dieffenbachia ingestions: are they a problem? J Toxicol Clin Toxicol. 1991;29(4):485-91.

3. Jaspersen-Schib R, Theus $L$, Guirguis-Oeschger $M$, Gossweiler B, Meier-Abt PJ. Serious plant poisonings in Switzerland 1966-1994. Case analysis from the Swiss Toxicology Information Center. Schweiz Med Wochenschr. 1996; 126:1085-98.

4. Cumpston KL, Vogel SN, Leikin JB, Erickson TB. Acute airway compromise after brief exposure to a Dieffenbachia plant. J Emerg Med. 2003;25(4):391-7. 